\title{
HOW THE CORPORATE GOVERNANCE RATINGS AFFECT THE FIRM VALUE: EMPIRICAL EVIDENCE FROM THE INDONESIA STOCK EXCHANGE
}

\author{
Amin A. *, Arniati T., Puspita D.A. \\ Faculty of Business and Economic, STIE Malang Malangkuçeçwara, Malang, Indonesia \\ ${ }^{\star}$ E-mail: arniati.abm@gmail.com
}

\begin{abstract}
This paper aims at assessing corporate governance by the instrumentality of ratings for a sample of 115 companies listed on the IDX during 2012-2016 in 575 cases. The novelty of this study emphasis by the corporate governance ratings developed for the companies listed on the IDX by using multidimensional data analysis techniques, namely Moderating Analysis Regression (MRA), and Earnings Quality index as moderation variable. The utility of current research underlines by the information related to CG ratings towards investors globally, thus supports the investment decision making.
\end{abstract}

\section{KEY WORDS}

Good corporate governance, firm value, moderating analysis regression, earning quality, investment decision making.

Today, global economic competition becomes a severe issue for governments and business. This issue affects the nation's financial at domestic and international level. To win this competitive competition, the national corporate victory against the abroad corporations is a must. This victory is necessary to build economic stability in the country of origin of the corporation so that corporate quality becomes an important aspect in shaping a country's financial security. The Corporate Governance (CG) system in Indonesia began to be known in 1997 when the economic crisis and the fall of the government regime at that time. Starting from the proposed improvement of the listing regulations on the Jakarta Stock Exchange (now the Indonesia Stock Exchange or IDX) governing the rules for issuers on IDX required to appoint an independent commissioner and form an audit committee in 1998, CG began to introduce to all public companies in Indonesia.

The system has become increasingly popular and essential in the past decade in Indonesia for two main reasons. First, CG is one of the keys to a company's success in growing and developing. This system is considered beneficial for the long term as well as a strategy to win the global business competition. Next, the economic crisis in Asia and Latin America that occurred in the 2000s is believed to have arisen because of the failure of proper CG application by the corporations that dominate the region. The company's board, as the primary stakeholder, has a significant influence on CG. Important decisions such as the appointment of members of the board, dividend policy, and company budget were born from the board. Although the decision represents all the company's shareholders, full responsibility remains with the board members. In carrying out this process, CG has an indicator called Good Corporate Governance (GCG).

This paper aims at assessing corporate governance by the instrumentality of ratings for a sample of 115 companies listed on the IDX during 2012-2016 in 575 cases. In addition to that, current research has the goal of investigating the empirical relationship between corporate governance ratings and firm value using CG index. There are considering both CG's performance index measures and shareholders satisfaction index measures. CG's performance index measures acknowledge as management's commitment to CG; the board of director's structure and function; and work field and performance control. While shareholders satisfaction index measures annual report transparency and disclosure; and minor shareholders rights fulfillment. All variables being public stocks-adjusted. The novelty of this study emphasis by the corporate governance ratings developed for the companies listed on the 
IDX by using multidimensional data analysis techniques, namely Moderating Analysis Regression (MRA), and Earnings Quality index as moderation variable. The utility of current research underlines by the information related to CG ratings towards investors globally, thus supports the investment decision making.

\section{LITERATURE REVIEW}

CG is a series of processes, policies, and rules that affect the goals, management, and control of a company or corporation (Krehnke, 2007). CG is a subject that has many aspects, where one of its topics is accountability and mandate responsibility. This topic specifies the implementation of guidelines and mechanisms to ensure ethical behaviour and protect the interests of shareholders (Bebchuk, Cohen, \& Ferrell, 2009). Another focus is on economic efficiency which states that the corporate governance system must aim at optimising financial results, with a strong emphasis on the welfare of shareholders (Gompers, Ishii, \& Metrick, 2007). Good Corporate Governance (GCG) are the principles that underlie a method and mechanism of corporate management based on legislation and business ethics (Hartono, 2017). GCG principles generally consist of five main criteria, namely, transparency, accountability, responsibility, independence, and fairness (Aguilera Cuervo-Cazurra, 2009). In implementing GCG, the corporate board has the responsibility for each transaction, activity, decision, and effectiveness of the company's performance. The application of GCG principles can improve company performance and long-term economic value for investors and stakeholders, in another way, their Company Value.

The Company Value (CV) is the market value of the company's shares that reflects the wealth of the owner. The higher the stock price indicates, the more elevated the owner's wealth. We need to remember that the CV is the result of investor perceptions that affect the worth of published shares. Investors will choose to invest in companies with maximum company value because it can provide maximum shareholder prosperity (Huss \& Britzelmaier, 2014). The maximum company value achieves if the company can operate by reaching the targeted profit. This target obtains if the company can implement GCG. One indicator of CV is Price to Book Value (PBV), which is the comparison of the market price of the firm stock with its Book Value (BV). A high PBV ratio indicates a high stock price. PBV affects market confidence and prospects for the company's stability in the future. Companies that run well generally have PBV above 1, which shows a market value higher than the book value (Argandoña, 2012).

Another rate used to measure CV, but PBV is the Tobins' $Q$ ratio which is an assessment of market performance. This ratio reflects the company's market value compared with others based on their assets and net worth (Rossi \& Panggabean, 2012). CV formed through the indicators of the stock value is a dramatic influence for investment opportunities. Investment expenditure gives a positive signal about the company's growth in the future, thus increasing stock prices as an indicator of corporate value (Arniati, Puspita, Amin, \& Pirzada, 2019). If the market value reflects the company's noted assets only, then Tobin's $Q$ ratio will be equal as 1 . The broader proportion means that their market value is more extensive than valuable assets worth and otherwise. The smaller ratio than 1 indicates that their stock is undervalued. This ratio is the most precision measurement to count the management effectivity using their economic sources. The previous research conducted by Salim \& Yadav (2012) shows how this ratio applies in the capital structure, which later affects the firm's performances. However, only six sectors involved in this research, namely construction; consumer product; industrial product; plantation; property; trading and service. They found that this ratio is the results of the firm's growth and performance affected by the implementation of GCG. It will affect their accounting sector which reflects not just on their return (RoA, the return of assets, and RoE, the performance of equity) and earning (EpS, earning per share), but also their Short Term Debt (STD), Long Term Debt (LTD), and Total Debt (TD). Based on the data provided by Investor Responsibility Research Center (IRRC), Gompers, Ishii, and Metrick (2007) redevelop a 'Governance Index' $(G)$ to proxy the level of shareholder rights at various type of firm 
which more vary than their previous paper in 2003. Both documents conceived an investment strategy that becomes a trend in most shareholders, they tend to purchased shares in the lowest-G firms ('Democracy' firms with strong shareholder rights) and sold shares in the highest-G firms ('Dictatorship' firms with weak shareholder rights) which earned enormous abnormal returns for more than 8 percent per year.

In the perspective of management theory, managers who are selfish and risk-averse tend to allocate resources from investments that do not increase the value of the company to more profitable ventures. This reflex indicates that the value of the company will rise if upper management controls the behaviour of lower management not to waste the company's resources. This waste could find in both inappropriate investments and asset shrinking. Thus, the application of GCG as a system that regulates and controls the company is expected to provide and increase the value of the company for shareholders (Guna \& Herawaty, 2010). Also, there is notice that the firms with intents shareholder had higher firm value, profits, and sales growth but lower capital expenditures and fewer corporate acquisitions. Foerster \& Huen (2004) concluded that markets react significantly to the economic marginal 'news' related to CG ranks in Northern America. This evidences supported by Drobetz \& Pensa (2011) which stated that better CG highly correlates with better operating performance, higher stock returns, and higher market valuation in Eastern Europe.

The common previous research use differences in legal systems between countries to investigate if these differences affect firm valuation and firm performance. This theory proved to be a prevalent research topic and the anti-director index introduced by La Porta in 1998 (Spamann, 2010) that used numerous times in academic research as a measure of countrylevel corporate governance. The uncaptured aspect is the standard used in country-level management, the fact that CG attributes at the country-level still allow them some flexibility for choosing individual governance attributes. The international paper on this topic has limited due to the enormous costs involved in gathering individual governance provisions for a large global sample. Previous papers mostly use the global governance database provided by RiskMetrics such as Strange, Filatotchev, Buck, \& Wright (2009); Chhaochharia and Laeven (2009); or Bruno and Claessens (2010). Hence, there is still much room for further research using these new data sources.

The results of previous studies show the tendency that CG practices affect the CG index on public companies, which positively related to firm value. According to the International Finance Corporation (2014), the CG index consists of a commitment to CG; structure and functioning of the Board of Directors; control environment and processes; transparency and disclosure; and rights of minority shareholders.

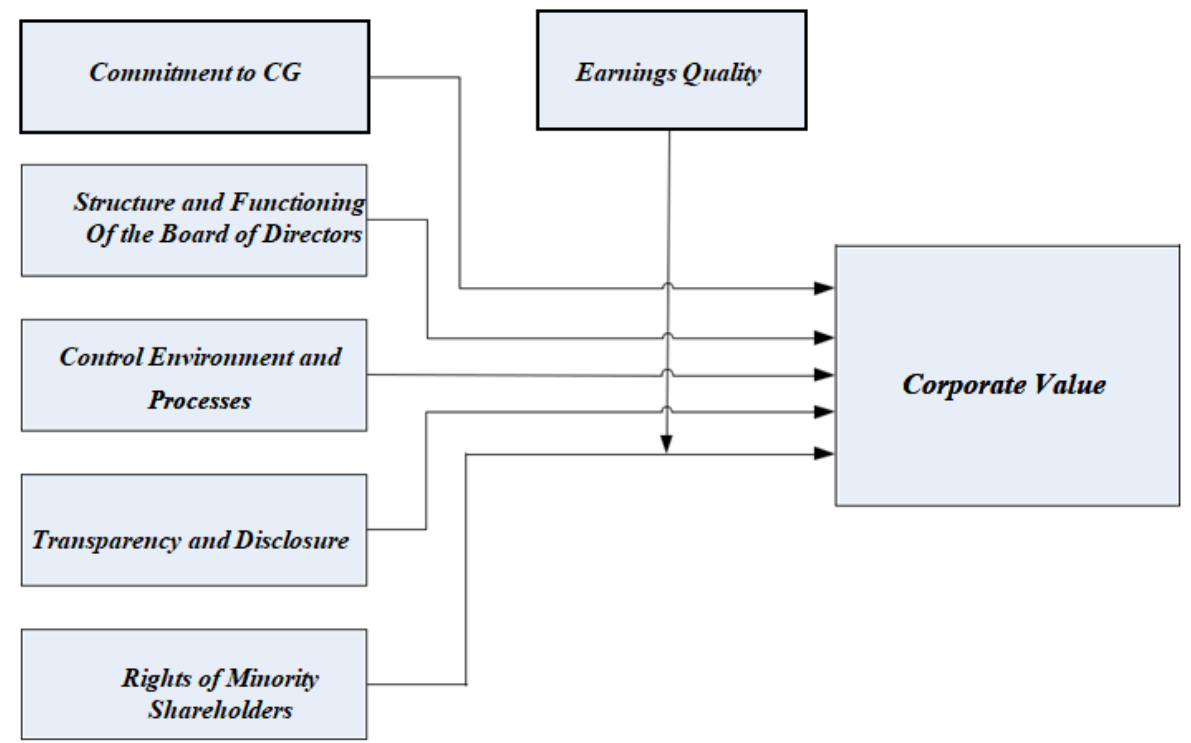

Figure 1 - Research framework 
The framework contains the variables used in this study. The five variables tested as components and their correlation with CG will be discussed further in the following paragraphs.

Commitment to CG basis is to ensure that they promote shareholder value. To support it, The Directorial Board usually apply strict independence standards. All directors elected annually by the majority vote of the Governance Committee also (Cremers, Masconale, \& Sepe, 2016). The board focused on key business priorities, such as the strategic role of the board, the role of the board in risk management (including Cybersecurity), and the succession planning and people development (Boix \& Svolik, 2013). The directors usually are stockholders which established the firm's policies guide governance and business integrity. This double-role seems adequate because they are the perfect person that knows what the real firm requirements are (Ostrom \& Ostrom, 2015). The boards have direct access to middle management to ensure their accountability (which includes evaluation process of middle management and CEO). The board must practice promoting effective oversight and continuous improvement through evaluation and education (Gabrusewicz, 2014). All of them related directly to the structure and functioning of the board directors.

A board of directors is a panel of people who are elected to represent shareholders of the firm. Every public company is required to install a board of directors legally. The nonprofit organizations and many private companies also name a board of directors even when they are not supposed to do that. The board is conscientious for protect shareholders' interests, establishing policies for management, oversight of the corporation or organization, and making decisions about important issues a company or organization faces (Demise, 2006). The board needs to represent shareholder and management interests and that it is usually a perfect idea for the board to include both their internal and external members. There is often an internal and external director. An internal director is a member of the committee invests in the company and manages the interests of shareholders, officers, and employees. An external director is a member who represents the opinions and interests of those outsides of the company (Erhardt, Werbel, \& Shrader, 2003). From the explanation above, this paper concludes the structure of the board of directors below in Fig 2.

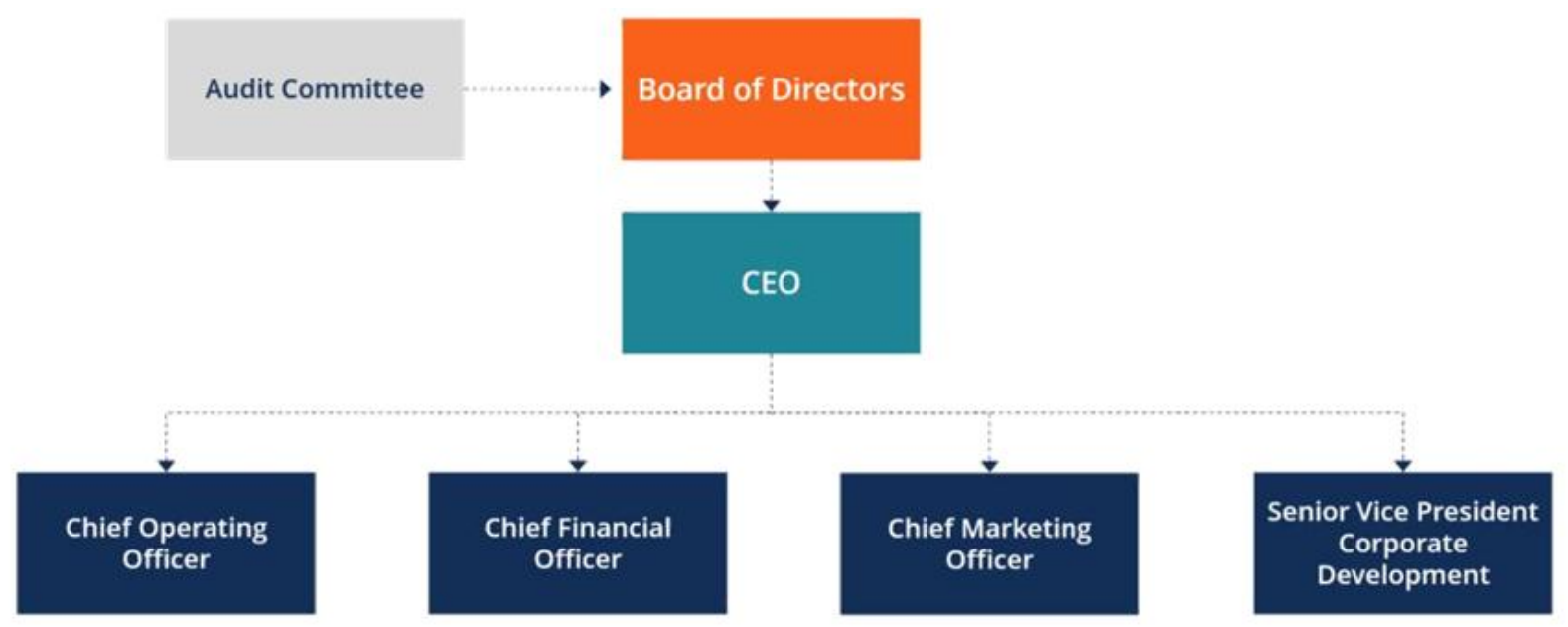

Figure 2 - Structure of the director's board

The board of directors structure tends to vary around the world. In certain countries in Asia and Europe, the structure often split into two main boards: executive and supervisory. The executive committee arranged of company insiders who elected by their employees and shareholders representative. In most firm, the executive board is headed up by the company CEO or a managing officer. The committee typically tasks them to supervising daily operations in the business. The supervisory board notices itself with a broader spectrum of issues when dealing with the company. This type of board acts similar to the typical board. The chairman of 
the committee varies, which always headed up by someone other than the preeminent executive officer.

There are three types of firm's internal controls, namely preventative, detective and corrective. Preventive controls deter problems before they arise. Detective controls are needed to discover issues as soon as they appear. Corrective authorities remedy control problems that found. Also, internal controls often segregated into two categories: general controls and application controls. General controls are designed to make sure an organization's control environment is stable and well managed. Application controls prevent, detect, and correct transaction errors and fraud (Al-Zwyalif, 2015). Leng and Ding (2011) aimed discovered that internal control disclosure is positively related to directors' remuneration and their education level, while negatively related to the proportion of state ownership. Adeyemi and Adenugba (2011) revealed that both internal controls and external audit are in no small extent, accountable for bad CG. The failure to effectively implement internal controls contributed significantly to poor CG. Lakshan \& Wijekoon (2012) argued that GCG requires the adoption of a risk management systems approach to protect the interests of stakeholders and shareholders, as well as ensure the existence of operational controls. Johnstone, $\mathrm{Li}$, and Rupley (2011) provided evidence that changes in CG characteristics occur concurrently with the remediation of internal control material weaknesses. Mihaela \& Iulian (2012) asserted that CG and internal control should not consider and sustained independence. An organization without an efficient long-term view of leadership and effective internal control mechanisms cannot be sustainable. CG is not entirely effective without reasonable internal control. Suyono \& Hariyanto (2012) showed that internal control, internal audit, and organizational commitment have a significant positive relationship with GC in Indonesia.

The importance of transparency has been widely recognized, resulting in numerous rules and regulations being introduced overtime to ensure timely and reliable disclosure of financial information. This importance is later creating standards to which companies must adhere. CG in today's global environment has become more complex and dynamic due to increased regulatory requirements and greater scrutiny. These problems are creating increased responsibilities for the board of directors to comply with rigorous governance standards and also coping with increasing demand for Transparency and Disclosure (T\&D) (Fung, 2014). Therefore, there is an increase in the number and complexity of accounting standards and other regulatory requirements for disclosure around the world to protect the investing public. Thus, corporations must provide adequate, accurate, and timely information to shareholders and the public regarding financial performance, liabilities, ownership, and CG issues which are essential if investors want to make informed judgments on the risks and rewards of any investment (OECD, 2011). Beeks \& Brown (2006) found out that companies with GCG also disclose more information. Those companies which are weak in management are lacking financial disclosure and transparency.

Minority shareholders' protection has become a legal requirement for GCG. The security of minority shareholders is, therefore, a function of certain fundamental legal principles, the distortion of which will invariably impinge upon the interest of the minority and as a consequence, create undue majoritarian hegemony. This function could be antithetical to GCG (De Cesari, 2012). In CG, the use of the words 'majority' and 'minority' does not aim at creating strains and tension between shareholders but endeavor to entrench corporate democracy taking into consideration relations of domination and subordination. Minority shareholders have certain legal rights. Their rights determined by the law of the state where the company was incorporated (Kirkbride, Letza, Smallman, 2009). Without state laws that grant minority shareholders certain rights and protections, those minority shareholders are vulnerable to the oppressive actions of the majority shareholders. They will have a small ability to sell their interests quickly or protect their investment. Among the widely recognised minority shareholders rights are (Huyghebaert \& Wang, 2012):

Fiduciary duty owed by significant shareholders. This right means that the majority of shareholders must deal with minority shareholders with sincerity, honesty, loyalty, and fairness. 
Minor shareholders have the right to expect company officers and directors to act in the company's best interests and compliance with the shareholder's agreement.

Minority Discount. This discount is assigned to minority shares when a company values its shares in preparation to sell or transfer ownership. This discount on minority shares reflects the fact that minority shares are not as valuable because they do not provide as much company ownership as other shares. Ironically, minority shareholders can buy shares for less than other investors and still receiving many of the same benefits of stock ownership. This advantage only belongs to the minority shareholder.

Benefit from shareholdings. Minor shareholders have the right to benefit from dividends and selling shares for a profit. However, these rights can be suppressed by those in control. If a minority shareholder believes that major shareholder is suppressing their rights to benefit, it is time to consult with a legal attorney.

Based on all of these arguments, the research hypothesis leads to the correlation and positive impact between variables on earnings quality and corporate value (CV). Therefore, this paper seeks the answer to this hypothesis.

\section{METHODS OF RESEARCH}

The sample of this study was companies that listed on IDX from 2012 to 2016 . The preliminary survey results on IDX recorded the number of companies listed up to 2016 was 138 companies. Based on sample selection, obtained 115 companies that meet the completeness of the data. Observations made in a 5-year period, which resulted in 575 cases of representation. This study uses secondary data, namely company data published on IDX, namely:

- Company's annual report which consists of stories from the Board of Commissioners of the Directors and Financial Statements; balance sheet, income statement and cash flow; and notes to financial statements.

- CG components, namely: commitment to CG; structure and functioning of the Board of Directors; control environment and processes; transparency and disclosure; and rights of minority shareholders.

Research variables group into independent variables, dependent variables, and moderation variables. The independent variable is the $C G$ disclosure index consisting of commitment to CG; structure and functioning of the Board of Directors; control environment and processes; transparency and disclosure; and rights of minority shareholders. The measurement of variables uses the CG disclosure score reported by the company in the annual report. The dependent variable is a CV, which is the value of the company measured by the Tobin- $Q$ ratio using the following formula:

$$
\text { Tobin's Q-Ratio }=\frac{\mathrm{ME}+(\mathrm{ME}+\mathrm{PS}+\mathrm{Debt})}{\mathrm{TA}}
$$

Where: $\mathrm{ME}=$ Value of stock price; $\mathrm{PS}=$ Preferred stock value; Debt $=$ Total debt - current assets + inventory; TA $=$ Total assets.

The moderating variable is earnings quality, which is the quality of company earnings measured by the value of accrual discretion developed by Kothari, Leone, \& Wasley (2005) using a proxy for performance-adjusted discretionary accruals. Accurately, this paper estimates the value of accrual discretion as follows:

$$
\left.\mathrm{T}_{\text {Accr }(\mathrm{i} ; \mathrm{t})}=\alpha_{0}+\alpha_{1}(1 / \text { Assetsi, }-1)\right)+\alpha_{2} \mathrm{ReV}_{\mathrm{i} ; \mathrm{t}}+\alpha_{3} \mathrm{PPE}_{\mathrm{i} ; \mathrm{t}}+\alpha_{4} \mathrm{ROA}_{\mathrm{i} ; \mathrm{t}}+{ }_{\mathrm{i} ; \mathrm{t}}
$$

The residuals of this regression model are discretionary accruals. The researcher uses the absolute value of discretionary accruals (DisAccr) multiplied by -1 as a proxy for earnings quality. 
The analytical method uses two stages, namely Regression Analysis (RA) and Moderating Regression Analysis (MRA) with moderating variables. The statistical model of the combination of the two analytical methods used in this study:

$$
\begin{aligned}
& \mathrm{CV}=\alpha+\beta_{1} \text { CommitCG }+\beta_{2} \text { StrFuncBoD }+\beta_{3} \text { ConEnvProces }+\beta_{4} \text { TransDisclos }+ \\
& \beta_{5} \text { RightsMinor }+\varepsilon \\
& \text { CV }=\alpha+\beta_{1} \text { CommitCG }+\beta_{2} \text { StrFuncBoD }+\beta_{3} \text { ConEnvProces }+\beta_{4} \text { TransDisclos }+
\end{aligned}
$$

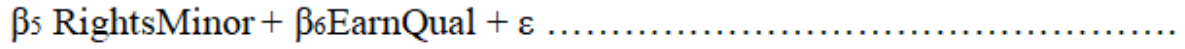

$$
\begin{aligned}
& \text { CV }=\alpha+\beta_{1} \text { CommitCG }+\beta_{2} \text { StrFuncBoD }+\beta_{3} \text { ConEnvProces }+\beta_{4} \text { TransDisclos }+ \\
& \beta_{5} \text { RightsMinor }+\beta_{6} \text { EarnQual }+\beta_{7} \text { CommitCG } * \text { EarnQual }+\beta_{8} \text { StrFuncBoD } \\
& \text { *EarnsQual }+\beta_{9} \text { ConEnvProces *EarnQual }+\beta_{10} \text { TransDisclos *EarnQual + } \\
& \beta_{11} \text { RightsMinor *EarnQual } \varepsilon
\end{aligned}
$$

Where: $\alpha$ - Constant; $\beta$ - Regression Coefficient; CV - Corporate Value; CommitCG - Commitment to CG; StrFuncBoD - Structure and functioning of the Board of Directors; ConEnvProces - Control environment and processes; TransDisclos - Transparency and disclosure; RightsMinor - Rights of minority shareholders; EarnQual - Earning quality; CommitCG*EarnQual - Interaction of commitment to CG with earning quality; StrFuncBoD Interaction of structure and functioning of the board of Directors with earnings quality; ConEnvProces - Interaction of control environment and processes with earnings quality; TransDisclos*EarnQual - Interaction of transparency and disclosure with earning quality; RightsMinor*EarnQual - Interaction of rights of minority shareholders with earning quality; $\varepsilon$ - Error term.

\section{RESULTS AND DISCUSSION}

\begin{tabular}{|c|c|c|c|c|c|c|c|}
\hline$n / n$ & $\begin{array}{c}\text { Commitment } \\
\text { to CG }\end{array}$ & $\begin{array}{c}\text { Structure } \\
\text { and functioning } \\
\text { of the BoD }\end{array}$ & $\begin{array}{c}\text { Control } \\
\text { environment } \\
\text { and } \\
\text { processes }\end{array}$ & $\begin{array}{l}\text { Transparency } \\
\text { and disclosure }\end{array}$ & $\begin{array}{c}\text { Rights of } \\
\text { minority } \\
\text { shareholders }\end{array}$ & $\begin{array}{c}\text { Corporate } \\
\text { Value }\end{array}$ & $\begin{array}{c}\text { Earnings } \\
\text { Quality }\end{array}$ \\
\hline Mean & 6.24 & 9.71 & 9.26 & 4.64 & 1.34 & 1.68 & 0.34 \\
\hline Median & 7.00 & 10.00 & 10.00 & 5.00 & 1.00 & 0.94 & 0.04 \\
\hline Mode & 7.00 & 10.00 & 10.00 & 5.00 & 1.00 & -2.39 & -0.55 \\
\hline Std. Dev & 1.25 & 2.05 & 2.08 & 1.18 & 1.16 & 2.50 & 3.99 \\
\hline Min Rate & 0.00 & 0.00 & 0.00 & 0.00 & 0.00 & -2.39 & -0.88 \\
\hline Max Rate & 7.00 & 12.00 & 16.00 & 6.00 & 5.00 & 18.40 & 56.82 \\
\hline
\end{tabular}

This result illustrates that most manufacturing companies have implemented seven items (out of 7 items) in the aspect of commitment to CG. These aspects include ownership of the CG charter, CG implementation rules, CG ethics or policy, expressing compliance with $C G$, and having officials responsible for CG implementation.

Table 1 - Research variable

CG implementation on the structure and functioning of the board of Directors has 13 items with an average score of 7.71 , the highest score of 12 , and the lowest score of 0 . The most found score (mode) is 10, with a percentage of $31.7 \%$ (Table 1). These results illustrate that most manufacturing companies have implemented 10 items (out of 12 items) in the structure and functioning of the board of Directors aspects, including the composition and structure of the board of Directors, have independent commissioners, have committees to help the board of Directors, the role of the board of Commissionaires for directors, members of the 
board of Directors have a variety of expertise according to company needs, as well as holding meetings of the board of Directors periodically.

The implementation of environmental and process control aspects has 16 assessment items with an average score of 9.26 , the highest score of 16 , and the lowest score of 0 . The scoring mode is 10 , with an appearance percentage of $46.5 \%$ (Table 1 ). This result illustrates that most manufacturing companies have implemented ten items (out of 16 items) aspects of environmental and process control. These items include adequate internal control, have an Audit Committee, have a risk limitation and risk management system, have an internal audit function, have a compliance program, and have internal and external audits.

Table 2 - Results of regression analysis and testing

\begin{tabular}{|c|c|c|c|c|c|}
\hline \multirow{2}{*}{ Model } & \multicolumn{2}{|c|}{$\begin{array}{c}\text { Unstandardized } \\
\text { Coefficients }\end{array}$} & \multirow{2}{*}{$\begin{array}{c}\begin{array}{c}\text { Standardised } \\
\text { Coefficients }\end{array} \\
\text { Beta }\end{array}$} & \multirow{2}{*}{$t$} & \multirow{2}{*}{ Sig. } \\
\hline & $B$ & $\begin{array}{l}\text { Std. } \\
\text { Error }\end{array}$ & & & \\
\hline \multirow{2}{*}{$\begin{array}{l}\text { (Constant) } \\
\text { Commitment to CG }\end{array}$} & .312 & .716 & & .435 & .663 \\
\hline & .267 & .124 & .134 & 2.147 & $\begin{array}{r}.032 \\
* *\end{array}$ \\
\hline Structure and functioning of the $\mathrm{BoD}$ & -.123 & .085 & -.101 & -1.443 & .150 \\
\hline Control environment and processes & .004 & .082 & .003 & .049 & .961 \\
\hline Transparency and disclosure & .109 & .115 & .052 & .945 & .345 \\
\hline Rights of minority shareholders & .212 & .109 & .098 & 1.942 & $\begin{array}{r}.053 \\
*\end{array}$ \\
\hline Earnings Quality & 2.138 & 2.729 & 3.419 & .784 & .434 \\
\hline \multirow{2}{*}{$\begin{array}{l}\text { ContEnviron*EarnQual } \\
\text { TranspDisc*EarnQual }\end{array}$} & -.316 & .193 & -5.160 & -1.641 & \multirow{2}{*}{$\begin{array}{l}.102 \\
.067\end{array}$} \\
\hline & -.365 & .198 & -2.807 & -1.837 & \\
\hline Right*EarnQual & 2.835 & .934 & 4.535 & 3.035 & $\begin{array}{r}.003 \\
* *\end{array}$ \\
\hline $\mathrm{R}$ & 0,233 & & & & \\
\hline R Square & 0,054 & & & & \\
\hline Adjusted R Square & 0,037 & & & & \\
\hline $\mathrm{F}$ & 3,145 & & & & \\
\hline Sig. & $0,001^{* * *}$ & & & & \\
\hline
\end{tabular}

Excluded Variables

\begin{tabular}{lccccr}
\hline Model & BetaIn & $t$ & Sig. & $\begin{array}{c}\text { Partial } \\
\text { Correlation }\end{array}$ & $\begin{array}{c}\text { Collinearity } \\
\text { Statistics } \\
\text { Tolerance }\end{array}$ \\
\hline Commit*EarnQual & $-16.801^{\mathrm{b}}$ & -1.975 & $\mathbf{. 0 4 9 * *}^{* *}$ & -.089 & $2.625 \mathrm{E}-$ \\
StrFuncBoD*EarnQual & $22.413^{\mathrm{b}}$ & 3.227 & $\mathbf{. 0 0 1}{ }^{* * *}$ & .144 & $3.887 \mathrm{E}-$ \\
\hline
\end{tabular}

a. Significance rate $* * * 1 \%, * * 5 \%, * 10 \%$

b. Dependent Variable: Corporate Value

c. Predictors: (Constant), Right1 EarnQual1, Transparency \& Disclosure 1, Right \& Shareholders 1, Commitment 1, Control \& Enviroment 1, structure and functioning of the BOD 1, TranspDisc1_EamQual1, ContEnviron1_EarnQual1, EarnQual1

Implementation on transparency and disclosure aspects has six items with an average score of 4.64. The highest rating is 6 , and the lowest score is 0 , with the most frequently occurring score is 5 , with a frequency of $69.3 \%$ (Table 1 ). This result illustrates that most 
manufacturing companies have implemented five items (out of 6 items) aspects of transparency and disclosure. These items include the presentation of financial statements in accordance with general accounting standards; declaration of significant transactions; transaction reports with related parties; off-balance-sheet activities; reviewing the Audit Committee on the critical elements of the financial statements; having a policy to disclose written information that is material (financial and non-financial); on-time share; and apply fairly to all stakeholders.

Implementation of the rights of minority shareholders aspect has five items with an average score of 4.64, the highest score of 5 and the lowest score of 0 . The most frequently found score is 1 , with a frequency of discovery of $49.5 \%$ (Table 1 ). This result illustrates that most manufacturing companies have implemented 1 item (out of 5 items) aspects of the rights of minority shareholders, including the preparation and invitation of an annual and extraordinary GMS without exception to all shareholders (sufficient notice; agenda and supporting material; proposal agenda items, participation privately or through a proxy, the right to ask questions, and the announcement of the results of the GMS).

The results of the analysis and testing of hypotheses in this paper present in Table 2. The table shows that commitment to $\mathrm{CG}$ and protection of rights of minority shareholders have a positive effect on the CV. The moderation test results show that earnings quality reinforces the positive influence of the CG index (structure and functioning of the board of directors and the rights of minority shareholders) on the CV. On the other hand, earning qualities strengthen the negative influence of the CG index (commitment to $C G$ and transparency \& disclosure) on the CV. Thus it can be concluded that commitment to CG and transparency \& disclosure have a positive effect on $\mathrm{CV}$, but turn negative when moderated by earnings quality. The positive influence of earnings quality moderation on the CV only found on the rights of minority shareholders aspects.

\section{CONCLUSION}

The results showed that commitment to $C G$ and the protection of rights of the minority shareholders had a positive effect on the CV. The moderated test results also show that earnings quality strengthens the positive influence of the structure \& functioning of the board of directors and the protection of rights of the minority shareholders on the value of $\mathrm{CV}$. Earning quality also gives a strong negative influence on the commitment to CG and transparency \& disclosures of $\mathrm{CV}$. The results concluded that commitment to $\mathrm{CG}$ and the protection of rights of minority shareholders had a positive effect on the CV. However, after being moderated by earning quality, the results obtained indicate that the protection of rights of minority shareholders still has a positive value on the CV but on the contrary commitment to CG shows an adverse effect on the CV.

The results of the study contributed to CG practices and assessment of GCG implementation in companies listed on IDX. Highlights on the application of GCG in the companies sampled are aspects of commitment to $C G$ and protection of rights of minority shareholders, which can effectively increase CVs with or without moderation in earnings quality. This aspect is undoubtedly seen as necessary by stakeholders, especially investors, who believe in the company's performance and stability as a result of applying GCG principles. Nonetheless, the aspect of protecting the rights of shareholders is still limited to the points of preparation and summons for the annual and extraordinary GMS that allows the participation of all shareholders without exception by ignoring other aspects of the rights of minority shareholders that can increase the trust value for long-term investment.

This study has limitations in accessing data related to qualitative CG implementation. The explanations revealed in the majority of the company's annual reports are incomplete, making it difficult to process the scoring and data analysis. The researcher uses an interpretation of the disclosure of the implementation of CG based on the researcher's point of view. Besides, this study uses the disclosure scoring aspects of CG with a score of 1 (revealing) and a score of 0 
(not revealing). Such disclosure scoring certainly has limited content of implementation value only limited to the information disclosed in annual public reports.

For further research, public companies in Indonesia still need to improve performance and hassle in several aspects of CG, namely environmental \& process control and protection of rights of minority shareholders. This is often overlooked but is quite essential to build a company's brand image so that it attracts greater investor interest and trust in the long run. While related to measurement and data collection, further research needs to supplement by distributing questionnaires to company officials relating to the implementation of CG in their place of work. This is done to obtain valid confirmation of the disclosure of CG items that are often not reported openly or even ignored in the company's annual report.

\section{REFERENCES}

1. Adams, R. B., Hermalin, B. E., \& Weisbach, M. S. (2010). The role of boards of directors in corporate governance: A conceptual framework and survey. Journal of Economic Literature. https://doi.org/10.1257/jel.48.1.58

2. Adeyemi, B., \& Adenugba, A. (2011). Corporate Governance in the Nigerian Financial Sector: the Efficacy of Internal Control and External Audit. Global Conference on Business \& Finance Proceedings.

3. Aguilera, R. V., \& Cuervo-Cazurra, A. (2009). Codes of good governance. Corporate Governance: An International Review. https://doi.org/10.1111/j.1467-8683.2009.00737.x

4. Argandoña, A. (2012). Stakeholder Theory and Value Creation. SSRN Electronic Journal. https://doi.org/10.2139/ssrn.1947317

5. Arniati, T., Puspita, D. A., Amin, A., \& Pirzada, K. (2019). The implementation of good corporate governance model and auditor independence in earnings' quality improvement. Entrepreneurship and Sustainability Issues. https://doi.org/10.9770/jesi.2019.7.1(15)

6. Al-Zwyalif, I. M. (2015). The Role of Internal Control in Enhancing Corporate Governance: Evidence from Jordan. International Journal of Business and Management. https://doi.org/10.5539/ijbm.v10n7p57

7. Bebchuk, L., Cohen, A., \& Ferrell, A. (2009). What matters in corporate governance. Review of Financial Studies. https://doi.org/10.1093/rfs/hhn099

8. Beekes, W., \& Brown, P. (2006). Do better-governed Australian firms make more informative disclosures? Journal of Business Finance and Accounting. https://doi.org/10.1111/j.1468-5957.2006.00614.x

9. Boix, C., \& Svolik, M. W. (2013). The foundations of limited authoritarian government: Institutions, commitment, and power-sharing in dictatorships. Journal of Politics. https://doi.org/10.1017/S0022381613000029

10. Brickley, J. A., \& Zimmerman, J. L. (2010). Corporate governance myths: Comments on Armstrong, Guay, and Weber. Journal of Accounting and Economics. https://doi.org/10.1016/j.jacceco.2010.10.002

11. Bruno, V., \& Claessens, S. (2010). Corporate governance and regulation: Can there be too much of a good thing? Journal of Financial Intermediation. https://doi.org/10.1016/j.jfi.2009.10.001

12. Chhaochharia, V., \& Laeven, L. (2009). Corporate governance norms and practices. Journal of Financial Intermediation. https://doi.org/10.1016/j.jfi.2008.10.001

13. Cremers, K. J. M., Masconale, S., \& Sepe, S. M. (2016). Commitment and entrenchment in corporate governance. Northwestern University Law Review.

14. De Cesari, A. (2012). Expropriation of minority shareholders and payout policy. British Accounting Review. https://doi.org/10.1016/j.bar.2012.09.002

15. Demise, N. (2006). Board of directors. In Corporate Governance in Japan: From the Viewpoints of Management, Accounting, and the Market. https://doi.org/10.1007/978-4-43130920-8_6

16. Drobetz, W., \& Pensa, P. (2011). Capital Structure and Stock Returns: The European Evidence. SSRN Electronic Journal. https://doi.org/10.2139/ssrn.957302 
17. Erhardt, N. L., Werbel, J. D., \& Shrader, C. B. (2003). Board of Director Diversity and Firm Financial Performance. Corporate Governance. https://doi.org/10.1111/1467-8683.00011

18. Foerster, S. R., \& Huen, B. C. Y. (2004). Does corporate governance matter to Canadian investors? Canadian Investment Review.

19. Fung, B. (2014). The Demand and Need for Transparency and Disclosure in Corporate Governance. Universal Journal of Management. https://doi.org/10.13189/ujm.2014.020203

20. Gabrusewicz, T. (2014). Social aspects of corporate governance. Studia PrawnoEkonomiczne.

21. Gompers, P., Ishii, J., \& Metrick, A. (2007). Corporate governance and equity prices. Corporate Governance and Corporate Finance: A European Perspective. https://doi.org/10.4324/9780203940136

22. Guna, W. I., \& Herawaty, D. A. (2010). Pengaruh Mekanisme Good Corporate Governance, Independensi Auditor, Kualitas Audit Dan Faktor Lainnya Terhadap Manajemen Laba. Bisnis Dan Akuntansi.

23. Hartono, R. (2017). Pelaksanaan Peraturan Menteri Bumn Nomor: Per-01/Mbu/2011 Tentang Penerapan Tata Kelola Yang Baik (Good Corporate Governance) Pada BUMN (Studi Kasus Di PT. Perkebunan Nusantara IV). Jurnal Mercatoria. https://doi.org/10.31289/mercatoria.v9i2.432

24. Hillman, A. J., \& Dalziel, T. (2003). Boards of directors and firm performance: Integrating agency and resource dependence perspectives. Academy of Management Review. https://doi.org/10.5465/AMR.2003.10196729

25. Huss, C., \& Britzelmaier, B. (2014). Intellectual Capital And Company's Value. International Journal of Management Cases. https://doi.org/10.5848/apbj.2008.00048

26. Huyghebaert, N., \& Wang, L. (2012). Expropriation of Minority Investors in Chinese Listed Firms: The Role of Internal and External Corporate Governance Mechanisms. Corporate Governance: An International Review. https://doi.org/10.1111/j.1467-8683.2012.00909.x

27. Johnstone, K., Li, C., \& Rupley, K. H. (2011). Changes in Corporate Governance Associated with the Revelation of Internal Control Material Weaknesses and Their Subsequent Remediation. Contemporary Accounting Research. https://doi.org/10.1111/j.1911-3846.2010.01037.x

28. Kirkbride, J., Letza, S., \& Smallman, C. (2009). Minority shareholders and corporate governance: Reflections on the derivative action in the UK, the USA and in China. International Journal of Law and Management. https://doi.org/10.1108/17542430910974031

29. Kothari, S. P., Leone, A. J., \& Wasley, C. E. (2005). Performance matched discretionary accrual measures. Journal of Accounting and Economics. https://doi.org/10.1016/j.jacceco.2004.11.002

30. Krehnke, D. C. (2007). Corporate governance. In Information Security Management Handbook, Sixth Edition.

31. Lakshan, A. M. I., \& Wijekoon, W. M. H. N. (2012). Corporate Governance and Corporate Failure. Procedia Economics and Finance. https://doi.org/10.1016/s2212-5671(12)00079-2

32. Leng, J., \& Ding, Y. (2011). Internal Control Disclosure and Corporate Governance: Empirical Research from Chinese Listed Companies. Technology and Investment. https://doi.org/10.4236/ti.2011.24029

33. Mihaela, D., \& lulian, S. (2012). Internal control and the impact on corporate governance, in Romanian listed companies. Innovation and Sustainable Competitive Advantage: From Regional Development to World Economies - Proceedings of the 18th International Business Information Management Association Conference.

34. OECD. (2011). Executive summary. OECD Economic Surveys: Ireland 2011. https://doi.org/10.1002/yd.20002

35. Ostrom, E., \& Ostrom, E. (2015). An Institutional Approach to the Study of Self-organization and Self-governance in CPR Situations. In Governing the Commons. https://doi.org/10.1017/cbo9781316423936.003 
36. Rossi, R. N., \& Panggabean, R. R. (2012). Analisis Pengaruh Penerapan Good Corporate Governance terhadap Kinerja Perusahaan. Binus Business Review. https://doi.org/10.21512/bbr.v3i1.1290

37. Salim, M., \& Yadav, R. (2012). Capital Structure and Firm Performance: Evidence from Malaysian Listed Companies. Procedia - Social and Behavioral Sciences. https://doi.org/10.1016/j.sbspro.2012.11.105

38. Spamann, H. (2010). The "anti-director rights index" revisited. Review of Financial Studies. https://doi.org/10.1093/rfs/hhp067

39. Strange, R., Filatotchev, I., Buck, T., \& Wright, M. (2009). Corporate governance and international business. Management International Review. https://doi.org/10.1007/s11575009-0001-z

40. Suyono, E. \& Hariyanto, E. (2012). Relationship between Internal Control, Internal Audit, and Organization Commitment with Good Governance: Indonesian Case. China-USA Business Review. https://doi.org/10.17265/1537-1514/2012.09.006 